\title{
THE OPPORTUNITIES AND CHALLENGES OF USING AIRBORNE LASER SCANNING FOR FOREST INVENTORIES IN LITHUANIA
}

\author{
Gintautas MOZGERIS, Aleksandras Stulginskis University, Institute of Forest Management and Wood Science, Studentų 13, \\ LT-53362 Akademija, Kaunas distr., Lithuania, gintautas.mozgeris@asu.lt \\ Ina BIKUVIENE், University of Applied Sciences, Faculty of Technologies, Department of Environmental Engineering, Pramonès \\ pr. 22, LT-50387Kaunas, Lithuania, ina.bikuviene@go.kauko.lt \\ Donatas JONIKAVICIUS, Aleksandras Stulginskis University, Institute of Forest Management and Wood Science, Studentų 13, \\ LT-53362 Akademija, Kaunas distr., Lithuania, donatas.jonikavicius@asu.lt (corresponding author)
}

\begin{abstract}
The aim of this study was to test the usability of airborne laser scanning (ALS) data for stand-wise forest inventories in Lithuania based on operational approaches from Nordic countries, taking into account Lithuanian forest conditions and requirements for stand-wise inventories, such as more complex forests, unified requirements for inventory of all forests, i.e. no matter the ownership, availability of supporting material from previous inventories and high accuracy requirements for total volume estimation. Test area in central part of Lithuania (area 2674 ha) was scanned using target point density $1 \mathrm{~m}^{-2}$ followed by measurements of 440 circular field plots (area $100-500 \mathrm{~m}^{2}$ ). Detailed information on 22 final felling areas with all trees callipered (total area $42.7 \mathrm{ha}$ ) was made available to represent forest at mature age. Updated information from conventional stand-wise inventory was made available for the whole study area, too. A two phase sampling with nonparametric Most Similar Neighbor estimator was used to predict point-wise forest characteristics. Total volume of the stand per 1 ha was predicted with an root mean square error of $18.6 \%$, basal area $-17.7 \%$, mean diameter - $13.6 \%$, mean height $-7.9 \%$ and number of tree $-42.8 \%$ at plot-level with practically no significant bias. However, the relative root mean square errors increased 2-4 times when trying to predict forest characteristics by three major groups of tree species - pine, spruce and all deciduous trees taken together. Main conclusion of the study was that accuracy of predicting volume using ALS data decreased notably when targeting forest characteristics by three major groups of tree species.
\end{abstract}

Keywords: forest inventory, laser scanning, compartment, stand volume

\section{INTRODUCTION}

Airborne laser scanning (ALS) has become an operational technique to collect acceptable quality measurement based data for forest inventories (Næsset et al. 2004, Hyyppä et al. 2008, Holopainen et al. 2010, Holopainen 2011). Forest inventory (FI) systems in some countries are already based on ALS data (Næsset et al. 2004, Næsset 2007, 2009). Stand-wise forest inventories (SWFI) are aimed to provide information required for tactical forestry planning and estimates of forest variables for all forest stands are needed (Holmgren 2004). Traditionally, boundaries of forest stands are delineated on remotely sensed images and visual estimations supported by some field measurements are used to get the needed forest variables. However, the costs and accuracy balance of conventional fieldwork-based stand-wise forest inventories meanwhile is considered to be unsatisfactory in many countries (Maltamo et al. 2006) and remote sensing and particularly ALS are considered to be the most powerful solutions to derive the forest resource information.

There are two basic methodological approaches used to derive the forest stand related information from the ALS data - the area based or the laser canopy height distribution (ABA) approach (Næsset 2002) and the individual tree crown (ITC) approach (Hyyppä et al. 1999, Yu et al. 2011, Li et al. 2012,Véga et al. 2014). In the area based approaches, the distributions of laser canopy heights across an area are evaluated and variables practically for any point in the forest are estimated using some set of reference field measured sample plots and various parametric and nonparametric estimation techniques, such as regression (Næsset 2002), k-Nearest Neighbor (Holopainen et al 2010), k-Most Similar Neighbor (Maltamo et al. 2006) or Random Forest (Yu et al. 2010). Final stand-level estimates are computed then as the average value of the individual point-wise estimates (Næsset 2004). There are numerous examples indicating that the ALS databased forest inventories are able to output basic stand characteristics with accuracies required to those of conventional SWFI based on interpretation of remotely sensed images and followed by intensive fieldworks (Holmgren 2004, Næsset 2007, Packalén and Maltamo 2007).

Copyright (C) 2017 The Authors. Published by Aleksandras Stulginskis University. This is an open-access article distributed under the terms of the Creative Commons Attribution License (CC-BY 4.0), which permits unrestricted use, distribution, and reproduction in any medium, provided the original author and source are credited. 
Current forest inventory practices in Lithuania can be divided into three broad approaches - stand-wise inventory, National forest inventory (NFI) by sampling methods and pre-harvesting inventory of forest compartment (Kuliešis 2008). Even the NFI plays an increasing role in generating forest statistics, the main source of forest related information that is used for tactical and operational forestry planning remains the stand-wise inventory. Lithuanian SWFI nowadays is based on visual delineation of compartments using on-screen mono interpretation of CIR orthophotos, supported by available delineations from previous forest inventories and other GIS data sets, followed by field visits to each compartment for a combination of visual and measurements based assessment of stand attributes. Forest management planning, especially when it regards the amounts of forest to be harvested during the main felling, requires reliable information on the resources. Sampling based surveys of mature forests were started in Lithuania in 2008-2009 (Kasperavičius 2009). They focused on statistically sound and compatible with the NFI estimates at forest enterprise level. Such slightly modified surveys are incorporated now in conventional stand-wise forest inventories. They are usually based on measurements of large number of sample plots, thus making forest inventory labor consuming and costly. Accuracy requirements for volume estimation at a compartment level $( \pm 20 \%$, however $\pm 15 \%$ since year 2011$)$ are on the margins affordable with the methods used currently. So, the use of remote sensing based solutions and particularly ALS is considered to be an option to increase the measurements-based component of Lithuanian forest inventories and meet the quality requirements without essential raise of costs involved.

The aim of our study was to test the usability of ALS data for stand-wise forest inventories in Lithuania based on operational approaches from Nordic countries, taking into account local conditions and requirements, such as more complex forests, similar requirements for inventory of all forests, i.e. no matter the ownership, availability of supporting material from previous SWFIs, high accuracy requirements for total volume estimation, etc.

\section{MATERIALS AND METHODS}

Study area. The test area (Dubrava forest) is situated in central part of Lithuania $\left(24^{\circ} 4^{\prime} \mathrm{E}\right.$ and $\left.54^{\circ} 50^{\prime} \mathrm{N}\right)$ with practically all country's forest conditions present here. Borders of compartments and their attributes for the test area were determined within the frames of conventional stand-wise inventory in 2002 and stored in a GIS database. All this information was updated using the near-infrared orthophotos from the summer of 2008 (Mozgeris et al. 2009) for geometry and growth models for attributes to represent 1.1.2009. For current study we use information from 1568 forest compartments on 2674 ha. Table 1 lists some general characteristics of compartments of the study area.

Table 1. Characteristics of compartments used for the study

\begin{tabular}{|l|c|c|c|c|c|c|c|c|}
\hline \multicolumn{1}{|c}{ Parameter } & \multicolumn{9}{c|}{ Prevailing tree species } \\
\cline { 2 - 10 } & Pine & Spruce & Oak & Ash & Birch & Black alder & Aspen & Gray alder \\
\hline Total area, ha & 1059 & 1069 & 110 & 18 & 225 & 154 & 12 & 27 \\
\hline Number of compartments & 526 & 647 & 78 & 11 & 164 & 113 & 10 & 19 \\
\hline Average age, y. & 73.4 & 56.2 & 63.1 & 53.8 & 58.6 & 42.8 & 59.4 & 49.8 \\
\hline
\end{tabular}

Remote sensing data: Study area was scanned using ALTM3100 instrument from $1500 \mathrm{~m}$ altitude and $70 \mathrm{kHz}$ pulse frequency or shooting density 1 point per $\mathrm{m}^{2}$ (resulting in more than 2 responses per square meter) in summer of 2008 (Figure 1.).

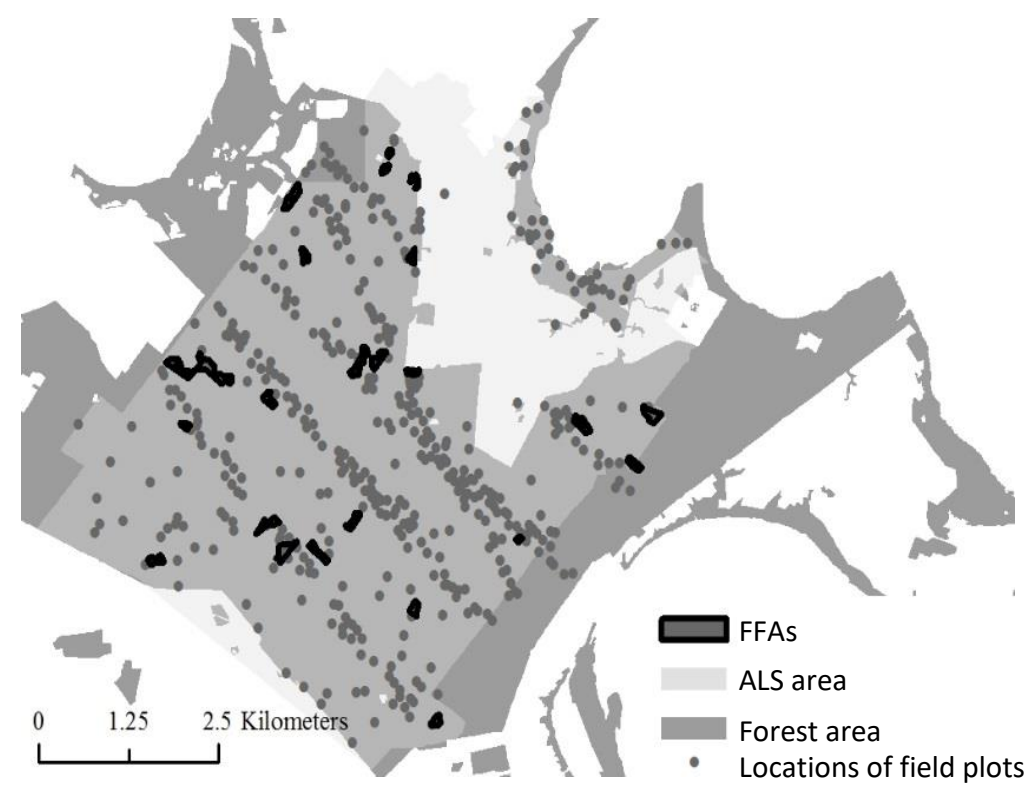

Figure 1. ALS area and locations of circular field plots and final felling areas used for validation 
Field data: 440 circular field plots (radius $5.64 \mathrm{~m}$ for trees having breast height diameter $6 \mathrm{~cm}$ and more and $12.62 \mathrm{~m}$ for trees having breast height diameter $14 \mathrm{~cm}$ and more) were established and measured within half a year after acquiring the remotely sensed data. Field plots were distributed aiming all prevailing tree species and age class combinations to be represented. First of all, one field plot was randomly located inside the core area of forest compartment along one out of five $200 \mathrm{~m}$ wide strips crossing the test area. Strips were located to maximize the representation of forest conditions of the test area. Next, additional sample plots were located in forest compartments with still unrepresented trees species and age class combinations. Standard dendrometric characteristics were measured for trees on the plots: polar coordinates of each tree, tree species, diameter, crown type, height for sample trees (not less than 1-3 sample trees for each forest element), etc. Volumes for all trees (including the volumes of stems, branches and volume distributions by merchantability classes) were later estimated utilizing the methods operational in Lithuanian forest inventories (Bikuviene et al. 2009) and used to get plot-wise estimates, including the shares of different tree species. Coordinates (X, $\mathrm{Y}$ and Z) of the center of each sample plot were measured using electronic tacheometer (Leica Smart Station GPS 1200 Series) expecting the accuracy not worse than $0.1 \mathrm{~m}$.

Methodology: In present study, a two phase sampling with nonparametric Most Similar Neighbor (MSN) estimator (Moeur and Stage 1995) was used to predict total volume per 1 ha at a plot level. Some other forest characteristics (basal area, mean height and diameter, number of trees) were predicted at a plot level, too.

The MSN or k-MSN method is a non-parametric nearest neighbor estimator which uses canonical correlation analysis to get a weighting matrix for selecting the $\mathrm{k}$ (here we used 4) most similar neighbors among the $2^{\text {nd }}$ phase (i.e. field sampled) units for each $1^{\text {st }}$ phase unit in terms of auxiliary ALS data. X-variables (or independent variables), originating from laser point clouds and Y-variable (or dependent variable, i.e. volume), based on field estimates were available for all field measured sample plots ( $2^{\text {nd }}$ phase units) and just X-variables were available for the $1^{\text {st }}$ phase units. The MSN method is well documented in the literature, including forest inventory applications with ALS data (Packalen and Maltamo 2007, Packalen 2009).

Canopy heights were computed from the ALS data by subtracting the digital terrain model from the orthometric heights. Next, canopy hits were extracted, assuming a canopy height less than $2 \mathrm{~m}$ as a ground hit. The first and last pulse response height distributions were created from the canopy height hits. Canopy height percentiles from 5 to $99 \%$, normalized differences and ratios of percentiles, indices of vertical density, percentiles of response intensity were computed to be used for prediction. The final list of heuristically selected X-variables included approximately 25 out of 169 candidate variables based on laser point cloud. Processing of ALS data was implemented by the vendor (Blom Kartta Oy, Finland).

Accuracy assessment: Estimation accuracies are discussed here at plots level of the study area. Plot-wise accuracies of predicting main forest characteristics were estimated using cross-validation technique. Bias and relative root mean square errors (RMSE), referring to the mean value of corresponding attribute on plots, were computed.

ArcGIS software was used for all manipulations with pre-processed input material.

\section{RESULTS AND DISCUSSION}

Plot-level prediction accuracies are summarized in Table 2. If total characteristics for the whole stand were taken into account only, insignificant bias for all variable should be noted. The volume per 1 ha was estimated with an RMSE of $18.6 \%$ (mean volume per 1 ha on the plots was $372 \mathrm{~m}^{3}$ ). For the basal area the RMSE was $17.7 \%$ (mean value $\left.30.9 \mathrm{~m}^{2}\right)$, for mean diameter $-13.6 \%(24.7 \mathrm{~cm})$, for mean height $-7.9 \%(21.6 \mathrm{~m})$ and for number of tree $-42.8 \%(594)$, respectively.

Table 2. Plot-level prediction accuracies (\% of the mean values)

\begin{tabular}{|l|c|c|c|c|c|c|c|c|c|}
\hline \multirow{2}{*}{\multicolumn{1}{|c}{ Variable }} & \multicolumn{2}{c|}{ Whole stand } & \multicolumn{2}{c|}{ Pine } & \multicolumn{2}{c|}{ Spruce } & \multicolumn{2}{c|}{ Deciduous trees } \\
\cline { 2 - 10 } & RMSE & Bias & RMSE & Bias & RMSE & Bias & & RMSE & Bias \\
\hline Volume per 1 ha & 18.6 & -0.4 & 89.35 & -10.05 & 57.29 & -9.81 & & 62.45 & 11.63 \\
\hline Basal area & 17.7 & 0 & 85.57 & -9.31 & 54.81 & -7.64 & & 61.43 & 12.91 \\
\hline Mean diameter & 13.6 & 0.6 & 33.00 & -0.55 & 35.65 & -3.41 & & 36.20 & 1.35 \\
\hline Mean height & 7.9 & -0.1 & 29.33 & -2.64 & 32.42 & -4.25 & & 29.10 & 1.40 \\
\hline Number of trees & 42.8 & 0.7 & 113.96 & -0.99 & 80.13 & -3.56 & & 91.96 & 21.28 \\
\hline
\end{tabular}

Both RMSEs and bias increased notably when trying to predict forest characteristics by three major groups of tree species - pine, spruce and all deciduous trees taken together. Negative bias for coniferous and positive for deciduous tree species should be noted, too.

The plot-level prediction accuracies when total values of main forest characteristics are estimated seem to be similar to the ones reported in numerous publications of mainly Nordic researchers (Næsset et al. 2004, Maltamo et al. 2006, Packalén 2009, Yu et al. 2010), no matter the average volume of stands in our study exceeds the one reported for other cases. The RMSEs and especially the bias increased several times when the forest characteristics were attempted to be predicted for pine, spruce and deciduous trees separately. Therefore we used tree species composition data available from the stand registers to divide total volumes by tree species in subsequent SWFI oriented study.

Utilization of ALS based forest inventory data in operational forest management planning is targeted currently in many similar studies (Holopainen et al. 2010, Holopainen 2011, Vastaranta et al. 2011). One of major objectives for 
Lithuanian SWFI today is to get volume estimates for premature-mature compartments with root mean square errors not exceeding $15 \%$. Starting from the year 2011 this requirement covers all forest being inventoried. Numerous solutions had been used to deal with that requirement. Traditional approach to combine visual assessment with relascope sample plots (Kuliešis 2008) received recently strong criticism because of large impact of human factor on the inventory results. Sampling based surveys of mature forests from years 2008-2009 (Kasperavičius 2009) and most resent solution to use thoroughly regulated relascope sample plots after the compartments are field inventoried followed by careful control of measurements are rather costly and may suffer from the same subjectivism present in stand-wise inventories. Approach to replace numerous forest inventory people cruising in the forest by objective, measurement based ALS data, indicated promising results for Lithuanian forest inventory.

So, to conclude, total volume of the stand per 1 ha was predicted using ALS data and nonparametric Most Similar Neighbor estimator with an root mean square error of $18.6 \%$, basal area $-17.7 \%$, mean diameter $-13.6 \%$, mean height $7.9 \%$ and number of tree $-42.8 \%$ at plot-level with practically no significant bias. However, both RMSEs and bias increased notably when targeting forest characteristics by three major groups of tree species. Our main conclusion for the moment is that ALS data can be incorporated in conventional Lithuanian stand-wise inventories without major changes of their design and support the volume estimates.

\section{REFERENCES}

1. Anonymous: Mokslinès studijos „Nuotolinių metodų taikymo miškų inventorizacijoje bei monitoringe galimybèms ištirti ir rekomendacijoms dèl šių metodų naudojimo parengti”, ataskaita [Potential of Remote Sensing Application for Forest Inventories and Monitoring and Development of Recommendations for Operational Use of Remote Sensing, Final Report], 2010. Lithuanian Forest Inventory and Management Planning Institute, 184 pp. [In Lithuanian, English summary].

2. Bikuvienè, I., Mozgeris, G., Žalkauskas, R. 2009. The influence of forest cover characteristics on the accuracy of LiDAR based digital terrain model. Proccedings of 4-th International Scientific conference Rural development 2009, pp. 217-222.

3. Breidenbach, J., Næsset, E., Lien, V., Gobakken, T., Solberg, S. 2010. Prediction of species specific forest inventory attributes using a nonparametric semi-individual tree crown approach based on fused airborne laser scanning and multispectral data. Remote Sensing of Environment, Vol. 114, pp. 911-924. https://doi.org/10.1016/j.rse.2009.12.004

4. Daniulis, J. 1998. Aerofotometodai [Aerial photographic methods], Vilnius, Enciklopedija, 248 pp. [In Lithuanian]

5. Eid, T., Gobakken, T., Næsset, E. 2004. Comparing stand inventories based on photo interpretation and laser scanning by means of cost-plus-loss analyses. Scandinavian Journal of Forest Research, Vol. 19, pp. $512-523$. https://doi.org/10.1080/02827580410019463

6. Holmgren, J. 2004. Prediction of tree height, basal area and stem volume in forest stands using airborne laser scanning. Scandinavian Journal of Forest Research, Vol. 19, pp. 543-553. https://doi.org/10.1080/02827580410019472

7. Holmgren, J. and Person, Å. 2004. Identifying species of individual trees using airborne laser scanning. Remote Sensing of Environment, Vol. 90, pp. 415-423.https://doi.org/10.1016/S0034-4257(03)00140-8

8. Holopainen, M. and Talvitie, T. 2006. Effect of data acquisition accuracy on timing of stand harvests and expected net present value. Silva Fennica, Vol. 40, Iss. 3, pp. 531-543. https://doi.org/10.14214/sf.335

9. Holopainen, M., Hyyppä, J., Vaario, L-M., Yrjälä, K. 2010. Implications of technological development to forestry. Invited book chapter. In: Mery, G., Katila P, Galloway, G., Alfaro, R.I., Kanninen, M., Lobovikov, M., Varjo, J. (eds.) Forest and Society Responding to Global Drivers of Change. IUFRO-World Series, Vol. 25, p. 157-182.

10. Holopainen, M., Vastaranta, M., Rasinmäki, J., Kalliovirta, J., Mäkinen, A., Haapanen, R. Melkas, T., Yu, X., Hyyppä, J. 2010. Uncertainty in timber assortment estimates predicted from forest inventory data. European Journal of Forest Research, Vol. 129, pp. 1131-1142. https://doi.org/10.1007/s10342-010-0401-4

11. Holopainen, M., Mäkinen, A., Rasinmäki, J., Hyytiäinen, K., Bayazidi, S., Pietilä, I. 2010. Comparison of various sources of uncertainty in stand-level net present value estimates. Forest Policy and Economics, Vol. 12, pp. 377-386, https://doi.org/10.1016/j.forpol.2010.02.009

12. Holopainen, M. 2011. Effect of airborne laser scanning accuracy on forest stock and yield estimates. Aalto University, School of Engineering, Department of Surveying. Aalto University Doctoral Dissertations 6/2011. Doctoral thesis. 160 pp. http://lib.tkk.fi/Diss/2011/isbn9789526040134/

13. Hyyppä, J. and Inkinen, M. 1999. Detecting and estimating attributes for single trees using laser scanner. The Photogrammetric Journal of Finland, Vol. 16, pp. 27-42.

14. Hyyppä, J., Hyyppä, H., Leckie, D., Gougeon, F., Yu, X. and Maltamo, M. 2008. Review of methods of small-footprint airborne laser scanning for extracting forest inventory data in Boreal forests. International Journal of Remote Sensing, Vol. 29, Iss. 5, pp. 1139-1366. https://doi.org/10.1080/01431160701736489

15. Jonikavičius, D. and Mozgeris, G. 2009. Estimation of Volumes for Mature Forests Using the K-nearest Neighbor Technique and Satellite Image. Proccedings of 4-th International Scientific conference Rural development 2009, Vol. 4, b. 2, pp. $235-240$.

16. Kasperavičius, A. 2009. Brandžių medynu inventorizacijos ateitis -pasirinkimo kryžkelèje [Reliable Inventory of Mature Stands - a Topic for Discussions among Foresters]. Mūsu girios, No. 4, pp. 20-22. [In Lithuanian]

17. Koch, B., Straub, C., Dees, M., Wang, Y., Weinacker, H. 2009. Airborne laser data for stand delineation and information extraction. International Journal of Remote Sensing, Vol. 30, Iss. 4, pp. 935-963. https://doi.org/10.1080/01431160802395284

18. Kuliešis, A. 2008. Mišku inventorizacija [Forest Inventory]. In: Mažeika, J.A. (Ed.). Forest Use and Logistic: Textbook. Lithuanian university of agriculture, Akademija, Kaunas r., pp. 227-287 [in Lithuanian] 
19. W. Li, Q. Guo, M.K. Jakubowski, M. Kelly. 2012. A new method for segmenting individual trees from the lidar point cloud. Photogrammetric Engineering and Remote Sensing, Vol. 78, Iss. 1, pp. 75-84. https://doi.org/10.14358/PERS.78.1.75

20. Maltamo, M., Malinen, J., Packalén, P., Suvanto, A. and Kangas, J. 2006. Nonparametric estimation of stem volume using airborne laser scanning, aerial photography and stand register data. Canadian Journal of Forest Research, Vol. 36, pp. 426-436. https://doi.org/10.1139/x05-246

21. Moeur, M., Stage A.R. 1995. Most similar neighbor: an improved sampling inference procedure for natural resource planning. Forest Science, Vol. 41, No. 2, pp. 337-359.

22. Mozgeris, G., Galaunè, A. and Palicinas, M. 2008. Systemy informacji geograficznej w urządzaniu lasu na Litwie - dekada praktycznego stosowania [Geographical information systems in forest management planning in Lithuania- a decade of practical application]. Sylwan, Vol. 152, No. 1, pp. 58-63. [In Polish]

23. Mozgeris, G., Galaunè, A., Jonikavičius, D. 2009. Fotoplanų, sudarytų ultralengvu orlaiviu atliktos aeronuotraukos pagrindu, geometrinis tikslumas [Geometrical accuracy of orthophoto maps developed on the base of ultra-light aircraft imaging]. Vagos, Vol. 82, No. 35, pp. 113-119. [In Lithuanian]

24. Næsset, E. 2002. Predicting forest stand characteristics with airborne scanning laser using a practical two-stage procedure and field data. Remote Sensing of Environment, Vol. 80, pp. 88-99. https://doi.org/10.1016/S0034-4257(01)00290-5

25. Næsset, E. 2004. Accuracy of forest inventory using airborne laser scanning: evaluating the first Nordic full-scale operational project. Scandinavian Journal of Forest Research, Vol. 19, pp. 554-557. https://doi.org/10.1080/02827580410019544

26. Næsset, E., Gobakken, T., Holmgren, J., Hyyppä, H., Hyyppä, J., Maltamo, M., Nilsson, M., Olsson, H., Person, A., Söderman, U. 2004. Laser scanning of forest resources: the Nordic experience. Scandinavian Journal of Forest Research, Vol. 19, pp. 482499. https://doi.org/10.1080/02827580410019553

27. Næsset, E. 2007. Airborne laser scanning as a method in operational forest inventory: status of accuracy assessments accomplished in Scandinavia. Scandinavian Journal of Forest Research, Vol. 22, pp. $433-442$. https://doi.org/10.1080/02827580701672147

28. Næsset, E. 2009. Effects of different sensors, flying altitudes, and pulse repetition frequencies on forest canopy metrics and biophysical stand properties derived from small-footprint airborne laser data. Remote Sensing of Environment, Vol. 113, Iss. 1, pp. 148-159. https://doi.org/10.1016/j.rse.2008.09.001

29. Nothdurft, A., Saborowski, J., Breidenbach, J. 2009. Spatial prediction of forest stand variables. European Journal of Forest Research Vol. 128, pp. 241-251. https://doi.org/10.1007/s10342-009-0260-Z

30. Ørka, H.O., Næsset, E., Bollandsås, O.M. 2009. Classifying species of individual trees by intensity and structure features derived from airborne laser scanner data. Remote Sensing of Environment, Vol. 113, pp. $1163-1174$. https://doi.org/10.1016/j.rse.2009.02.002

31. Packalén, P. and Maltamo, M. 2007. The k-MSN method for the prediction of species-specific stand attributes using airborne laser scanning and aerial photographs. Remote Sensing of Environment, Vol. 109, pp. 328-341. https://doi.org/10.1016/j.rse.2007.01.005

32. Packalén, P. 2009. Using airborne laser scanning data and digital aerial photographs to estimate growing stock by tree species. University of Joensuu, Faculty of Forest Sciences. Dissertationes Forestales, No 77, 41 pp.

33. Tomppo, E. 2005. The Finnish multisource National Forest Inventory - small area estimation and map production. In: A.Kangas and M.Maltamo (eds.), Forest Inventory: Methodology and Applications, Springer, pp. 191-220.

34. Vastaranta, M., Holopainen, M., Yu, X., Hyyppä, J., Hyyppä H., Viitala, R. 2011. Predicting stand-thinning maturity from airborne laser scanning data. Scandinavian Journal of Forest Research, Vol. 26, No. 2, pp. $187-196$. https://doi.org/10.1080/02827581.2010.547870

35. C. Véga, A. Hamrouni, S. El Mokhtari, J. Morel, J. Bock, J.-P. Renaud, et al. 2014. PTrees: A point-based approach to forest tree extraction from lidar data. International Journal of Applied Earth Observation and Geoinformation, Vol. 33, pp. 98-108 https://doi.org/10.1016/j.jag.2014.05.001

36. Yu, X., Hyyppä, J., Vastaranta, M., Holopainen, M. and Viitala, R. 2011. Predicting individual tree attributes from airborne laser point clouds based on random forest technique. ISPRS Journal of Photogrammetry and Remote Sensing, Vol. 66, pp. 28-37. https://doi.org/10.1016/j.isprsjprs.2010.08.003

37. Yu, X., Hyyppä, J., Holopainen, M. and Vastaranta, M. 2010. Comparison of area-based and individual tree-based methods for predicting plot-level forest attributes. Remote Sensing, Vol. 2, No. 6, pp. 1481-1495. https://doi.org/10.3390/rs2061481 